\title{
Liming Characteristics of a High-Calcium Dry Flue Gas Desulfurization By-Product and a Class-C Fly Ash
}

\author{
Jason R. Burgess-Conforti ${ }^{*}$, David M. Miller ${ }^{1}$, Kristofor R. Brye ${ }^{1}$, \\ Lisa S. Wood' ${ }^{1}$, Erik D. Pollock ${ }^{2}$ \\ ${ }^{1}$ Department of Crop, Soil, and Environmental Sciences, University of Arkansas, Fayetteville, AR, USA \\ ${ }^{2}$ Stable Isotope Laboratory, University of Arkansas, Fayetteville, AR, USA \\ Email: jrburges@uark.edu,dmmiller@uark.edu, kbrye@uark.edu, lswood@uark.edu, epolloc@uark.edu
}

How to cite this paper: Burgess-Conforti, J.R., Miller, D.M., Brye, K.R., Wood, L.S. and Pollock, E.D. (2016) Liming Characteristics of a High-Calcium Dry Flue Gas Desulfurization By-Product and a Class-C Fly Ash. Journal of Environmental Protection, 7, 1592-1604.

http://dx.doi.org/10.4236/jep.2016.711131

Received: September 19, 2016

Accepted: October 25, 2016

Published: October 28, 2016

Copyright $\odot 2016$ by authors and Scientific Research Publishing Inc. This work is licensed under the Creative Commons Attribution International License (CC BY 4.0).

http://creativecommons.org/licenses/by/4.0/

(c) (i) Open Access

\begin{abstract}
Due to coal's availability and low cost, coal combustion continues to be the United States' primary energy source. However, coal combustion produces large quantities of waste material. Some coal combustion by-products (CCBs) have chemical and physical characteristics that make them potentially useful as soil amendments. The objectives of this study were to characterize a relatively new, high-calcium dry flue gas desulfurization (DFGD) by-product and compare its agronomic liming potential to a Class-C fly ash (FA) and reagent-grade calcium carbonate $\left(\mathrm{CaCO}_{3}\right)$. Calcium carbonate equivalence (CCE), degree of fineness (DOF), and effective neutralizing value (ENV) for each CCB were determined using standard methods. The CCBs and $\mathrm{CaCO}_{3}$ were also incubated with an acidic ( 4.5) clay sub-soil at application rates equivalent to $0,0.5,1$, and 2 times the soil's lime requirement and compared to an unamended control. Soil $\mathrm{pH}$ was then measured periodically during a 40-day incubation. The ENV of $79.4 \%$ for the DFGD by-product and $57.3 \%$ for the FA were comparable to those of commercially available liming materials, but were significantly lower $(P<0.05)$ than that of reagent-grade $\mathrm{CaCO}_{3}$. After 40 days of incubation at the $0.5 \times$ application rate, both $\mathrm{CCBs}$ raised the $\mathrm{pH}$ of the clay soil to only 5.0, while the $\mathrm{CaCO}_{3}$ raised the $\mathrm{pH}$ to 6.5. After 40 days at the $1 \times$ rate, all three materials had raised the soil $\mathrm{pH}$ to between 6.5 and 7.0, although the FA increased the soil $\mathrm{pH}$ more slowly than did the other two materials. At the $2 \times$ rate, both CCBs increased the soil $\mathrm{pH}$ to between 7.5 and 8.0, while the $\mathrm{CaCO}_{3}$ increased the soil $\mathrm{pH}$ to only 7.0. Both CCBs appear to be useful as soil liming materials, although care should be taken to avoid over-application, as this may make the soil too alkaline for optimum plant growth.
\end{abstract}




\section{Keywords}

Coal Combustion By-Products, Agricultural Lime, Fly Ash, Flue Gas Desulfurization

\section{Introduction}

Coal combustion for energy production accounted for $39 \%$ of the 3.9 billion kilowatthours of electricity generated in the United States in 2014 [1]. Although natural gas is expected to eventually surpass coal as the primary fossil fuel source for electrical power generation in the United States, the ready availability and low cost of coal will likely allow coal to continue to be a major source of energy for approximately the next 35 years [1]. However, in addition to electricity, the coal-combustion process also produces large quantities of waste materials. In 2008, it was estimated that more than 123 million $\mathrm{Mg}$ of coal combustion by-products (CCBs) were produced, making CCBs the second largest waste stream in the United States behind municipal solid waste [2]. In 2007, only $44 \%$ of the CCBs generated in the United States were beneficially reused, which left 68 million $\mathrm{Mg}$ to be disposed of in landfills or surface impoundments [3]. The primary beneficial reuse fly ash is in concrete and concrete products, which represents $43 \%$ of beneficially reused fly ash. As of 2012 in the United States, 310 active on-site landfills and 735 on-site surface impoundments were used to dispose of CCBs that were not beneficially reused [4].

Several types of waste products are produced from the combustion of coal for power generation. Fly ash (FA) is a CCB that is removed from flue gases by various types of particle-filtration equipment at coal-fired power plants. Fly ash consists of particles that have been fused into spherical, glassy, amorphous aluminosilicates and is classified into one of two categories depending on the composition of the coal being burned. Class- $\mathrm{C}$ FA has a high calcium (Ca) concentration (25\% to $35 \%)$ and is derived from the burning of lignite and subbituminous coals, whereas Class-F FA has a low Ca concentration ( $0 \%$ to $10 \%)$ and originates from the burning of anthracite and bituminous coals [5]. Class-C FA is often referred to as "high-lime ash" and is a common by-product of coalfired power plants burning low sulfur coals from Wyoming and Montana [6].

A more recently produced waste material is flue gas desulfurization (FGD) by-products which result from emissions-control processes that inject a calcium sorbent into the flue gases to trap and remove sulfur dioxide $\left(\mathrm{SO}_{2}\right)$ from the emissions streams. Dry FGD (DFGD) systems often remove $\mathrm{SO}_{2}$ and FAs simultaneously, resulting in a byproduct that is a mixture of $\mathrm{FA}$, unreacted sorbent, calcium sulfite $\left(\mathrm{CaSO}_{3} \cdot 1 / 2 \mathrm{H}_{2} \mathrm{O}\right)$, and calcium sulfate $\left(\mathrm{CaSO}_{4} \cdot 2 \mathrm{H}_{2} \mathrm{O}\right)$ [7]. In response to recent environmental regulations, coal-fired power plants have combined conventional desulfurization processes with the injection of activated carbon to remove mercury $(\mathrm{Hg})$ (personal communication, Mark Cantrell, Arkansas Electric Power, 2016). This new emissions-control process has resulted in the generation of new DFGD by-products that may be chemically dissimilar from DFGD by-products produced previously. 
Because they contain unspent sorbent, DFGD by-products are typically alkaline and have the potential to be used as substitutes for agricultural lime. Dry FGD by-products containing Class-C FA can have particularly high concentrations of $\mathrm{Ca}$ and are often described as high-Ca DFGD by-products. The growing concern regarding long-term storage of CCBs has led to increased interest in finding beneficial uses for these byproducts. High-Ca CCBs may have potential for use in agriculture as a liming material, which can lead to a reduction in the volume of CCBs destined for disposal in landfills and surface impoundments, while helping to ameliorate soil acidification.

It is estimated that $25 \%$ to $30 \%$ of the world's soils are acidic enough to cause reductions in crop yields, decreased bioavailability of essential plant nutrients, and increased availability of potentially phytotoxic elements such as aluminum (Al) and manganese (Mn) [8]. Acidification of soils may be caused by a variety of processes including acidic precipitation and leaching of basic cations, but is most often caused by nitrification, the process whereby ammonium $\left(\mathrm{NH}_{4}^{+}\right)$is oxidized to nitrate $\left(\mathrm{NO}_{3}^{-}\right)$, which yields protons (i.e., $\mathrm{H}^{+}$ions) [9]. Regular application of liming materials, such as lime $\left(\mathrm{CaCO}_{3}\right)$, burnt lime $(\mathrm{CaO})$, hydrated lime $\left[\mathrm{Ca}(\mathrm{OH})_{2}\right]$, and dolomitic limestone $\left[\mathrm{CaMg}\left(\mathrm{CO}_{3}\right)_{2}\right]$, have been used historically to raise soil $\mathrm{pH}$ back to desired levels after years of acidification has lowered the soil $\mathrm{pH}$ beyond the minimum desired $\mathrm{pH}$ range for optimal plant growth. The presence of highly soluble $\mathrm{CaO}$ and $\mathrm{Ca}(\mathrm{OH})_{2}$ in Class-C FA and DFGD by-products enhances the potential for increasing soil $\mathrm{pH}$ above 7 and neutralizing soil acidity beyond the site of incorporation [10].

Considering that DFGD by-products are a relatively new CCB that has been minimally studied, the objectives of this study were to characterize a high-Ca DFGD byproduct and compare its agronomic liming potential to a Class-C FA and reagent-grade $\mathrm{CaCO}_{3}$. It was hypothesized that due to the high Ca concentrations of Class-C FAs, the coal by-products would be as effective as $\mathrm{CaCO}_{3}$ at increasing soil $\mathrm{pH}$ at the $1 \times$ application rate, and more effective at the $2 \times$ application rate.

\section{Materials and Methods}

\subsection{Initial Soil Collection and Characterization}

A grab sample of soil was collected from the 122 to $155-\mathrm{cm}$ depth interval of a Pickwick silt loam (fine-silty, mixed, semiactive, thermic Typic Paleudults) [11] located under a Loblolly pine (Pinus taeda) plantation at the University of Arkansas Agricultural Research and Extension Center in Fayetteville, Arkansas. This soil was chosen for its acidic $\mathrm{pH}(\sim 4.5)$ and high clay content. The soil was air-dried at $21^{\circ} \mathrm{C}$ for $7 \mathrm{~d}$ and ground to pass a 2 -mm sieve. Soil texture was determined to be clay (i.e., $37 \%$ sand, $20 \%$ silt, $43 \%$ clay) using a modified 12-hr hydrometer method [12]. The liming requirement of the soil (to achieve $\mathrm{pH}$ 7.0) was measured using the Shoemaker, Mclean and Pratt (SMP)

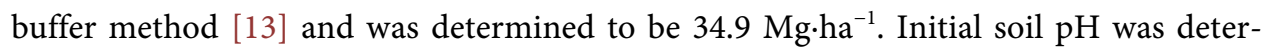
mined potentiometrically using a 1:1 (v:v) soil:0.01 $M \mathrm{CaCl}_{2}$ slurry.

\subsection{Liming Reagents}

The three liming materials used in this experiment were reagent-grade $\mathrm{CaCO}_{3}$, a Class- 
C FA, and a high-Ca, DFGD by-product. The Class-C FA was collected by an electrostatic precipitator and a silo baghouse from the Flint Creek Power Plant in Benton County, Arkansas [14]. The DFGD by-product was generated by a dry scrubber using an Alstom Novel Integrated Desulfurization design at the John W. Turk Power Plant in Hempstead County, Arkansas (personal communication, Mark Cantrell, 2015). Both power plants burn subbituminous coal from the Powder River Basin in Wyoming (personal communication, Mark Cantrell, Arkansas Electric Power, 2015). The John W. Turk power plant utilizes calcium hydroxide $\left[\mathrm{Ca}(\mathrm{OH})_{2}\right]$ as the sorbent in the desulfurization process (personal communication, Mark Cantrell, Arkansas Electric Power, 2015). Trace element concentrations of the Class-C FA and DFGD by-product were determined by inductively coupled plasma mass spectrometry (ICP-MS) following a microwave digestion in concentrated $\mathrm{HNO}_{3}$.

\subsection{Effective Neutralizing Value}

The effective neutralizing value (ENV) of the liming materials was calculated using the degree of fineness (DOF) and the $\mathrm{CaCO}_{3}$ equivalence (CCE). The DOF was determined in triplicate by passing each of the three liming materials through 20-, 60-, and 100mesh sieves (0.84-, $0.25-$, and $0.15-\mathrm{mm}$ mesh size, respectively) and calculating the percentage of material by weight that passed through each sieve relative to the $20 \mathrm{~g}$ of initial material. Sieving of the material was conducted in accordance with ASTM C110-14 by manually sieving in a lateral and vertical motion, while occasionally jarring the sieve, for a total of 10 minutes [15]. Calcium carbonate equivalence was determined potentiometrically using an Orion 710a $\mathrm{pH}$ meter and an Orion 9107bn $\mathrm{pH}$ probe (Thermo Fisher Scientific, Waltham, MA) by adding $100 \mathrm{~mL}$ of $1 \mathrm{~N}$ hydrochloric acid $(\mathrm{HCl})$ to $2.0 \mathrm{~g}$ of liming material and back-titrating to $\mathrm{pH} 7.0$ with $1 \mathrm{~N}$ sodium hydroxide $(\mathrm{NaOH})$ in accordance with ASTM C25-11 [16]. The ENV was calculated using the following equation:

$$
\mathrm{ENV}=\frac{(A+B+C) \times \mathrm{CCE}}{100}
$$

where $A$ is equal to 0.4 times the percentage of particle passing a 20 -mesh sieve minus the percentage of particle passing a 60 -mesh sieve, $B$ is equal to 0.8 times the percentage of particle passing a 60 -mesh sieve minus the percentage of particle passing a 100-mesh sieve, and $C$ is equal to 1.0 times the percentage particle passing a 100 -mesh sieve.

\subsection{Incubation Study}

Samples were prepared in triplicate for each of the three liming materials (i.e., reagent-grade $\mathrm{CaCO}_{3}, \mathrm{FA}$, and DFGD) and an unamended control that were destructively sampled at nine sampling times (i.e., $0,5,10,15,20,25,30,35$, and $40 \mathrm{~d}$ of incubation). Therefore, there were a total of 270 samples prepared initially for incubation ( 3 liming materials $\times 9$ time points $\times 3$ rates $\times 3$ replicates +1 control $\times 9$ time points $\times 3$ replicates). Liming materials were added to $20 \mathrm{~g}$ of air-dry soil in $50-\mathrm{mL}$ centrifuge tubes at application rates equivalent to $0 \times($ control), $0.5 \times, 1 \times$, and $2 \times(0,0.175,0.35$, and $0.7 \mathrm{~g}$, 
respectively) the soil's SMP buffer liming requirement. The tubes were thoroughly mixed by shaking for $5 \mathrm{~min}$ in a side-to-side shaker. Following mixing, samples were adjusted to a gravimetric moisture content of $22 \%$, based on the estimated field moisture capacity using deionized water [17]. Soil $\mathrm{pH}$ was measured by adding $20 \mathrm{~mL}$ of $0.01 \mathrm{M} \mathrm{CaCl}_{2}$ to $20 \mathrm{~g}$ of soil and mixing for $5 \mathrm{~min}$ in a side-to-side shaker. The $\mathrm{pH}$ of the resulting slurry was measured within 1 min of shaking the mixture. Soil $\mathrm{pH}$ measurements were made on triplicate samples every 5 days for the duration of the $40-\mathrm{d}$ incubation period.

\subsection{Statistical Analyses}

A one-factor analysis of variance (ANOVA) was conducted using the PROC MIXED procedure in SAS (version 9.3; SAS Institute Inc., Cary, NC) to evaluate the effect of liming material on their liming characteristics (i.e., DOF, CCE, and ENV). In addition, a three-factor ANOVA was conducted using the PROC MIXED procedure in SAS to evaluate the effects of liming material, rate, time, and their interactions on soil $\mathrm{pH}$ response. When appropriate, means were separated by least significant difference (LSD) at the $\alpha=0.05$ level.

\section{Results and Discussion}

\subsection{Initial Coal Combustion By-Product Characterization}

The mean $\mathrm{pH}$ of the three liming reagents used was 10.6, 12.3, and 8.4 for the DFGD by-product, FA, and reagent-grade $\mathrm{CaCO}_{3}$, respectively (Table 1 ). Both the DFGD byproduct and Class-C FA had elevated concentrations of trace elements which may warrant concern when being evaluated as a soil amendment. As a result of the high concentration of trace elements and soluble salts, the EC was 2.41 and $2.73 \mathrm{mS} \cdot \mathrm{cm}^{-1}$ for the DFGD by-product and Class-C FA, respectively (Figure 1). The EC of the reagentgrade $\mathrm{CaCO}_{3}$ was $0.042 \mathrm{mS} \cdot \mathrm{cm}^{-1}$. Continuous application of either the DFGD by-product or Class-C FA may cause an increase in soil EC and limit growth for plants that are sensitive to saline soils [10].

\subsection{Liming Characteristics}

All three liming characteristics evaluated in this study (i.e., CCE, DOF, and ENV) differed somewhat among liming materials. The CCE of the DFGD by-product (84.4\%) was lower $(P<0.05)$ than that for reagent-grade $\mathrm{CaCO}_{3}(100 \%)$, while CCE for Class-C FA $(60.3 \%)$ was also lower $(P<0.05)$ than that for the DFGD by-product (Figure 1$)$. In contrast to CCE, DOF for the DFGD by-product and Class-C FA were similar to one another $(P>0.05)$, averaging 94.1 and $95.1 \%$, but both were lower $(P<0.05)$ than that for reagent-grade $\mathrm{CaCO}_{3}$ (Figure 1). Similar to CCE, but in contrast to DOF, ENV of the DFGD by-product $(79.4 \%)$ was lower $(P<0.05)$ than that for reagent-grade $\mathrm{CaCO}_{3}$ (100\%), while CCE for Class-C FA $(57.3 \%)$ was also lower $(P<0.05)$ than that for the DFGD by-product (Figure 1). The low ENV for the Class-C FA can be attributed to the low CCE of $60.3 \%$. The DFGD CCE of $84.4 \%$ was similar to the values reported by Kost 


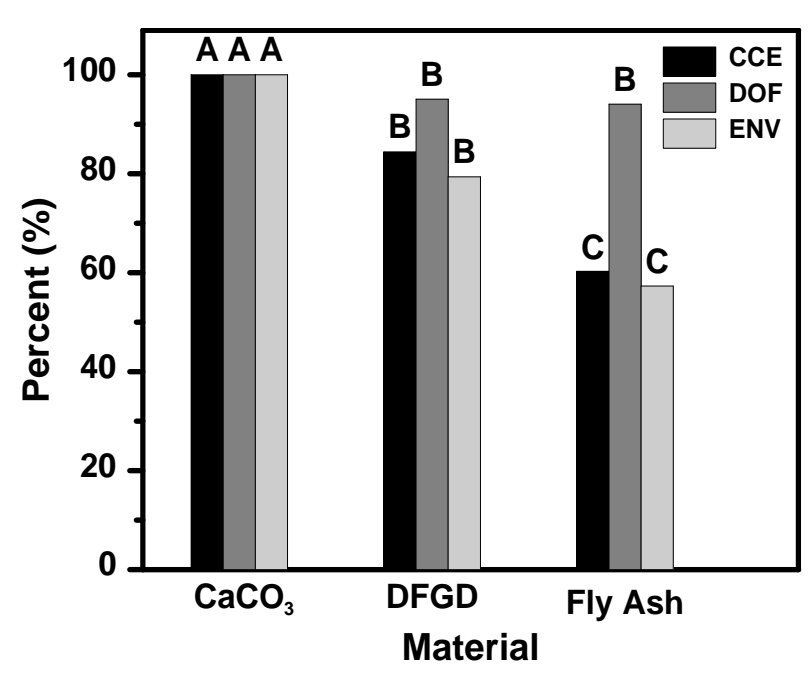

Figure 1. Calcium carbonate equivalence (CCE), degree of fineness (DOF), and effective neutralizing value (ENV) of reagent grade $\mathrm{CaCO}_{3}$, a high-Ca dry flue gas desulfurization by-product, and a class-C fly ash. Bars of the same color with different letters are significantly different $(P<$ $0.05)$.

Table 1. Mean chemical characteristics of a high-Ca dry flue gas desulfurization by-product from the John W. Turk Power Plant in Hempstead County, Arkansas and a Class-C fly ash from the Flint Creek Power Plant in Benton County Arkansas. The $\mathrm{CaCO}_{3}{ }^{\mathrm{a}}$ used in this experiment was reagent grade.

\begin{tabular}{|c|c|c|}
\hline Parameter & DFGD & Fly Ash \\
\hline $\mathrm{pH}^{\mathrm{b}}$ & 10.64 & 12.28 \\
\hline $\mathrm{EC}^{\mathrm{c}}\left(\mathrm{mS} \cdot \mathrm{cm}^{-1}\right)$ & 2.41 & 2.73 \\
\hline \multicolumn{3}{|c|}{ Trace element $\left(\mathrm{mg} \cdot \mathrm{kg}^{-1}\right)$} \\
\hline $\mathrm{Be}$ & 21.47 & 3.98 \\
\hline $\mathrm{V}$ & 137.68 & 57.71 \\
\hline $\mathrm{Cr}$ & 81.14 & 72.07 \\
\hline Co & 16.92 & 54.32 \\
\hline $\mathrm{Ni}$ & 43.08 & 29.19 \\
\hline $\mathrm{Cu}$ & 73.16 & 49.60 \\
\hline $\mathrm{Zn}$ & 140.83 & 50.50 \\
\hline As & 13.33 & 14.56 \\
\hline $\mathrm{Se}$ & 12.86 & 5.28 \\
\hline $\mathrm{Rb}$ & 1.38 & 48.39 \\
\hline $\mathrm{Cd}$ & 0.44 & 0.71 \\
\hline Cs & 1.27 & 2.60 \\
\hline $\mathrm{Hg}$ & 0.81 & $<0.01$ \\
\hline $\mathrm{Pb}$ & 0.20 & 108.24 \\
\hline Th & 3.43 & 28.40 \\
\hline $\mathrm{U}$ & 5.34 & 1.57 \\
\hline
\end{tabular}

a. $\mathrm{CaCO}_{3} \mathrm{pH}=8.44 ; \mathrm{EC}=0.042 \mathrm{mS} \cdot \mathrm{cm}^{-1} ; \mathrm{b} . \mathrm{pH}$ was measured in a 1:1 $0.01 \mathrm{M} \mathrm{CaCl}_{2}$ :solid slurry; c. EC was measured in a 2:1 DI water:Reagent slurry. 
et al. [7] who reported a CCE range of $41.6 \%$ to $97.7 \%$ for spray-dryer DFGD byproducts. Schlossberg et al. [18] stated that CCEs of Class-C FAs can be as high as $60 \%$, which is similar to the CCE of the Class-C FA examined in this experiment. Although $\mathrm{CCE}$ and ENV of the DFGD by-product were lower than that for reagent-grade $\mathrm{CaCO}_{3}$, most commercially available liming materials have ENVs ranging between 70 and 90, which is a range that includes the mean measured ENV for the DFGD by-product evaluated in this study [19].

\subsection{Incubation Study}

As expected, soil $\mathrm{pH}$ differed $(P<0.001)$ among liming material-application rate treatment combinations over time throughout the 40-d incubation period (Table 2). For all material-rate combinations, with the exception of the unamended control, soil $\mathrm{pH}$ generally sharply increased from day 0 to day 20 , followed by a period of either a more gradual soil $\mathrm{pH}$ increase or no further increase from day 20 to day 40 . The greatest differences among treatment combinations occurred among liming materials over time within an application rate.

Within $1 \mathrm{~min}$ after shaking the soil of the unamended control treatment, initial soil $\mathrm{pH}$ averaged 4.3 (Figure 2; Table 3). Soil $\mathrm{pH}$ in the unamended control remained virtually unchanged throughout the entire duration of the 40-d incubation period (Figure 2; Table 3). Within $5 \mathrm{~d}$ of incubation, the $\mathrm{pH}$ of soil receiving $\mathrm{CaCO}_{3}$ at the $0.5 \times$ application rate was significantly greater (5.8) than the $\mathrm{pH}$ of soil that was incubated with the Class-C FA or DFGD by-product (4.6) (Figure 2; Table 3). After $10 \mathrm{~d}$ of incubation, the $\mathrm{pH}$ of soil receiving the $0.5 \times$ rate of $\mathrm{CaCO}_{3}$ was significantly greater (6.3) than the pH of the DFGD- (5.0) and the FA-treated soil (4.7). From day 20 to day 40, soil pH did not differ between the DFGD and FA-treated soils. After $40 \mathrm{~d}$ of incubation, the $\mathrm{pH}$ of soil receiving the three liming materials had increased $(P<0.05)$ from a $\mathrm{pH}$ of 4.3 in the unamended control to 6.7, 5.0 and 4.8 for the reagent-grade $\mathrm{CaCO}_{3}$, DFGD by-product, and FA treatments, respectively.

Table 2. Analysis of variance summary of the effects of liming material (i.e., product), rate, and time (i.e., days into incubation), and their interactions on soil $\mathrm{pH}$ after 40 days of incubation in a clay soil.

\begin{tabular}{cc}
\hline Source of Variation & Soil pH \\
\cline { 2 - 2 } Liming material & $P$ \\
Rate & $<0.001$ \\
Liming material ${ }^{\star}$ rate & $<0.001$ \\
Time & $<0.001$ \\
Liming material ${ }^{*}$ time & $<0.001$ \\
Rate $^{*}$ time $^{*}{ }^{*}$ time & 0.002 \\
Liming material ${ }^{*}{ }^{\text {rate }}$ & $<0.001$ \\
\hline
\end{tabular}



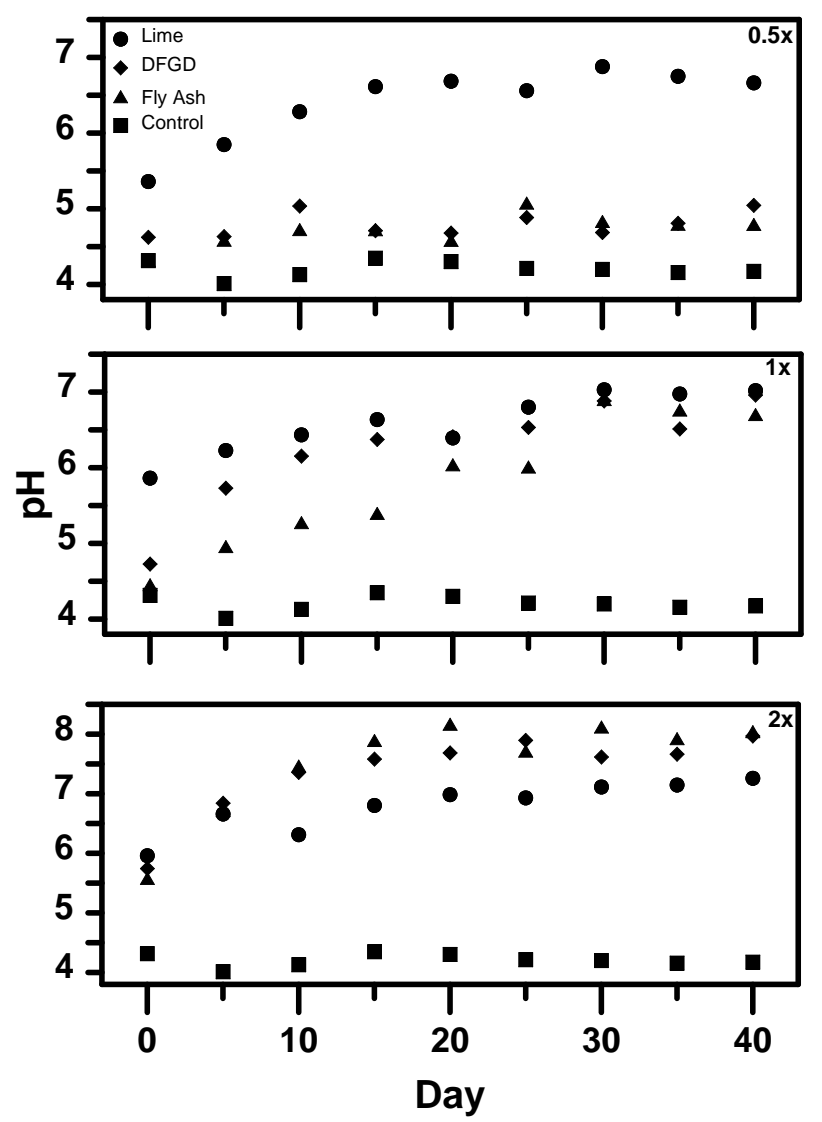

Figure 2. Soil $\mathrm{pH}$ response after incubation at $0.5 \times, 1 \times$, and $2 \times$ the Shoemaker-Mclean-Pratt (SMP) liming requirement with reagent-grade $\mathrm{CaCO}_{3}$, Class- $\mathrm{C}$ fly ash, and a high-Ca dry flue gas desulfurization (DFGD) by-product over a 40-day period.

Table 3. Mean $\mathrm{pH}$ of soil incubated with reagent-grade $\mathrm{CaCO}_{3}$, Class- $\mathrm{C}$ fly ash (FA), and a highCa dry flue gas desulfurization (DFGD) by-product at rates equivalent to $0.5 \times, 1 \times$, and $2 \times$ the Shoemaker-Mclean-Pratt (SMP) lime requirement over a 40-day period.

\begin{tabular}{|c|c|c|c|c|c|c|c|c|c|c|}
\hline \multirow[b]{3}{*}{ Day } & \multirow[b]{3}{*}{ Control } & \multicolumn{9}{|c|}{ Application Rate } \\
\hline & & \multicolumn{3}{|c|}{$0.5 \times$} & \multicolumn{3}{|c|}{$1 \times$} & \multicolumn{3}{|c|}{$2 \times$} \\
\hline & & FA & DFGD & $\mathrm{CaCO}_{3}$ & FA & DFGD & $\mathrm{CaCO}_{3}$ & FA & DFGD & $\mathrm{CaCO}_{3}$ \\
\hline 0 & 4.3 & 4.3 & 4.3 & 4.3 & 4.3 & 4.3 & 4.3 & 4.3 & 4.3 & 4.3 \\
\hline 5 & $4.0 \mathrm{e}^{\mathrm{a}}$ & $4.6 \mathrm{~d}$ & $4.6 \mathrm{~d}$ & $5.8 \mathrm{bc}$ & $5.0 \mathrm{~d}$ & $5.7 \mathrm{c}$ & $6.2 \mathrm{~b}$ & $6.7 \mathrm{a}$ & $6.8 \mathrm{a}$ & $6.7 \mathrm{a}$ \\
\hline 10 & $4.1 \mathrm{e}$ & $4.7 \mathrm{~d}$ & $5.0 \mathrm{~cd}$ & $6.3 \mathrm{~b}$ & $5.3 \mathrm{c}$ & $6.2 \mathrm{~b}$ & $6.4 \mathrm{~b}$ & $7.5 \mathrm{a}$ & $7.4 \mathrm{a}$ & $6.3 b$ \\
\hline 15 & $4.3 \mathrm{e}$ & $4.7 \mathrm{e}$ & $4.7 \mathrm{e}$ & $6.6 \mathrm{bc}$ & $5.4 \mathrm{~d}$ & $6.4 c$ & $6.6 \mathrm{bc}$ & $7.9 \mathrm{a}$ & $7.6 \mathrm{a}$ & $6.8 \mathrm{~b}$ \\
\hline 20 & $4.3 \mathrm{f}$ & $4.6 \mathrm{f}$ & $4.7 \mathrm{f}$ & $6.7 \mathrm{~cd}$ & $6.0 \mathrm{e}$ & $6.4 \mathrm{de}$ & $6.4 \mathrm{de}$ & $8.2 \mathrm{a}$ & $7.7 \mathrm{~b}$ & $7.0 \mathrm{c}$ \\
\hline 25 & $4.2 \mathrm{f}$ & $5.1 \mathrm{e}$ & $4.9 \mathrm{e}$ & $6.6 \mathrm{bc}$ & $6.0 \mathrm{~d}$ & $6.5 c$ & $6.8 \mathrm{bc}$ & $7.7 \mathrm{a}$ & $7.9 \mathrm{a}$ & $6.9 \mathrm{~b}$ \\
\hline 30 & $4.2 \mathrm{f}$ & $4.8 \mathrm{e}$ & $4.7 \mathrm{e}$ & $6.9 \mathrm{~d}$ & $6.9 \mathrm{~d}$ & $6.9 \mathrm{~d}$ & $7.0 \mathrm{~cd}$ & $8.1 \mathrm{a}$ & $7.6 \mathrm{~b}$ & $7.1 \mathrm{c}$ \\
\hline 35 & $4.2 \mathrm{~d}$ & $4.8 \mathrm{~d}$ & $4.8 \mathrm{~d}$ & $6.8 \mathrm{bc}$ & $6.8 \mathrm{bc}$ & $6.5 c$ & $7.0 \mathrm{~b}$ & $7.9 \mathrm{a}$ & $7.7 \mathrm{a}$ & $7.1 \mathrm{~b}$ \\
\hline 40 & $4.2 \mathrm{e}$ & $4.8 \mathrm{~d}$ & $5.0 \mathrm{~d}$ & $6.7 \mathrm{c}$ & $6.7 \mathrm{c}$ & $7.0 \mathrm{bc}$ & $7.0 \mathrm{bc}$ & $8.0 \mathrm{a}$ & $8.0 \mathrm{a}$ & $7.3 \mathrm{~b}$ \\
\hline
\end{tabular}

${ }^{\mathrm{a}}$ Means followed by a different letter within a row are significantly different $(P<0.05)$. 
At the $1 \times$ application rate, the DFGD by-product and FA were more effective at raising soil $\mathrm{pH}$ than at the $0.5 \times$ application rate. After $5 \mathrm{~d}$ of incubation, the $\mathrm{pH}$ of the soils incubated with the DFGD by-product and FA at the $1 \times$ application rate were greater $(P<0.05)$ than those in the soils receiving the same amendments at the $0.5 \times$ application rate (Figure 2; Table 3). After $10 \mathrm{~d}$ of incubation, and for the remainder of the 40- $\mathrm{d}$ incubation period, there was no difference in soil $\mathrm{pH}$ between reagent-grade $\mathrm{CaCO}_{3}$-amended soil and DFGD by-product-amended soil at the $1 \times$ application rate. Between 10 and $30 \mathrm{~d}$ of incubation at the $1 \times$ rate, soil pH was lower $(P<0.05)$ in the FA treatment than in the reagent-grade $\mathrm{CaCO}_{3}$ and DFGD by-product treatments, which did not differ. Soil $\mathrm{pH}$ did not differ among the three treatments at the $1 \mathrm{x}$ rate after $30 \mathrm{~d}$ of incubation. After $40 \mathrm{~d}$ of incubation at the $1 \times$ application rate, soil $\mathrm{pH}$ had increased $(P<0.05)$ from 4.3 in the unamended control to 7.0, 7.0, and 6.7 in the reagent-grade $\mathrm{CaCO}_{3}$, DFGD by-product, and FA treatments, respectively, which did not differ from one another. Compared to the 0.5 and $1 \times$ rates, soil $\mathrm{pH}$ responses were even more pronounced for the $2 \times$ application rate. After $10 \mathrm{~d}$ of incubation at the $2 \times$ rate, the $\mathrm{pH}$ of the soil that was amended with either the DFGD by-product or FA was greater $(P<$ 0.05) than that for the soil amended with the reagent-grade $\mathrm{CaCO}_{3}$ (Figure 2; Table 3). From day 10 to day 40, the $\mathrm{pH}$ of soil incubated with either the Class-C FA or DFGD by-product at the $2 \times$ application rate was greater $(P<0.05)$ than the $\mathrm{pH}$ of soil incubated with reagent-grade $\mathrm{CaCO}_{3}$. After $40 \mathrm{~d}$ of incubation, the $\mathrm{pH}$ of the soils receiving the three liming materials at the $2 \times$ application rate had increased from 4.3 in the unamended control to 7.3, 8.0, and 8.0 for the reagent-grade $\mathrm{CaCO}_{3}$, DFGD by-product, and FA treatments, respectively. The $\mathrm{pH}$ of soils incubated with either the Class-C FA or DFGD by-product was greater $(\mathrm{P}<0.05)$ than the $\mathrm{pH}$ of soil incubated with reagentgrade $\mathrm{CaCO}_{3}$, but did not differ from each other.

Both CCBs evaluated in this study have potential for use as soil liming materials. Calcium carbonate is relatively insoluble in water and the solubility of $\mathrm{CaCO}_{3}$ decreases rapidly above $\mathrm{pH} 6.0$ [20]. Once the soil $\mathrm{pH}$ exceeds 7.0, $\mathrm{CaCO}_{3}$ effectively becomes insoluble. This explains why the $\mathrm{pH}$ of soil amended with $\mathrm{CaCO}_{3}$ at the $2 \times$ application rate was not greater $(P>0.05)$ than that of the soil amended with $\mathrm{CaCO}_{3}$ at the $1 \mathrm{x}$ application rate. Calcium oxide $(\mathrm{CaO})$ and $\mathrm{Ca}(\mathrm{OH})_{2}$ have greater CCEs and continue to be soluble at greater $\mathrm{pHs}$ than $\mathrm{CaCO}_{3}$, resulting in greater equilibrium soil $\mathrm{pHs}$. The large concentrations of $\mathrm{CaO}$ and $\mathrm{Ca}(\mathrm{OH})_{2}$ typically present in the Class-C FA and DFGD by-product may explain why both liming materials were able to raise soil $\mathrm{pH}$ to 8.0 when amended at the $2 \times$ application rate.

The ability of the FA and DFGD by-product to raise soil $\mathrm{pH}$ to 7 over approximately the same time period as $\mathrm{CaCO}_{3}$ suggests that these by-products may be viable alternatives to traditional liming materials. The results of this experiment are similar to those reported in previous experiments where different CCBs were used. Punshon et al. [21] mixed a weathered FGD by-product with an acidic Paleudult (pH 5.4) at several application rates and reported an increase in soil $\mathrm{pH}$ from 5.5 to 8.1 in soil amended with by-product at application rates of 168 and $224 \mathrm{Mg} \cdot \mathrm{ha}^{-1}$. Adriano et al. [6] mixed a 
Class-F (i.e., low calcium) FA with an acidic Udifluvent ( $\mathrm{pH} 4.9$ ) at an application rate of $1120 \mathrm{Mg} \cdot \mathrm{ha}^{-1}$ and reported an increase in soil pH to 6.45. McCarty et al. [22] incubated soil with bed ash, FA, limestone-injection multistage burner (LIMB) residue, spray dryer residue (SDR), and $\mathrm{CaCO}_{3}$ with an acidic Hapludult ( $\mathrm{pH} 4.2$ ) at application rates ranging up to 22.4, 22.4, 22.5, 89.6 and $18.0 \mathrm{Mg} \cdot \mathrm{ha}^{-1}$ for the bed ash, LIMB, SDR residue, $\mathrm{FA}$ and $\mathrm{CaCO}_{3}$, respectively. The $\mathrm{pH}$ of the soils at the largest application rates were 8.0, 7.7, 7.1, 7.7 and 7.8 for the bed ash, LIMB residue, SDR residue, FA, and Ca$\mathrm{CO}_{3}$, respectively. The ability for the CCBs tested to increase soil $\mathrm{pH}$ in that experiment was in directly related to their respective CCEs [22]. When the means of soil $\mathrm{pH}$ were adjusted for covariance of CCE, there was no difference between the FA and $\mathrm{CaCO}_{3}$.

In this study, both the Class-C FA and DFGD by-product were able to raise the soil $\mathrm{pH}$ to 8.0 when applied at the $2 \times$ application rate. Most crops grow best in soils with a slightly acidic $\mathrm{pH}$ and can become stressed (i.e., due to a nutrient limitation or toxicity) if the soil $\mathrm{pH}$ is too alkaline. Therefore, caution must be exercised when using CCBs to avoid over-application and raising the soil $\mathrm{pH}$ so high that plant growth and productivity are negatively affected.

In addition to the ability to neutralize soil acidity at the surface, DFGD by-products contain large concentrations of $\mathrm{CaSO}_{4} \cdot 2 \mathrm{H}_{2} \mathrm{O}$ (i.e., gypsum), which has been shown to ameliorate subsoil acidity. Sumner et al. [23] reported a 20\% decrease in exchangeable $\mathrm{Al}$ at a depth of $105 \mathrm{~cm}$ following surface application of gypsum at a rate of $10 \mathrm{Mg} \cdot \mathrm{ha}^{-1}$. Gypsum-amended soil had a greater Ca saturation in the subsoil (i.e., the 5- to $105-\mathrm{cm}$ depth interval) than the unamended control. Wendell and Ritchey [24] observed a similar trend in acidic soil columns amended with a high-Ca DFGD by-product. Leachate$\mathrm{Al}$ concentrations were greater than that in the unamended control as a result of DFGD by-product addition, resulting in a decrease in the soil's exchangeable $\mathrm{Al}$ percentage [24].

Another possible use for these CCBs is in the reclamation of soils that have been disturbed by surface mining. Surface mining is a process can that cause severe soil acidification resulting from the exposure of Fe-sulfides in overburden materials [25]. Because acid mine lands are often very acidic $(\mathrm{pH}<4.50)$, there is potential for large-scale use of alkaline CCBs to neutralize overburden acidity without creating alkaline soils. By increasing soil $\mathrm{pH}$, the solubility and mobility of potentially toxic elements, such as arsenic, can be reduced [26]. Stehouwer et al. [25] and Stehouwer et al. [27] examined the effects on element solubility and mobility, as well as plant growth by amending minespoil material with DFGD by-products in a series of greenhouse studies. When applied at rates ranging from 30 to $120 \mathrm{~g} \mathrm{~kg}^{-1}$, fescue (Festuca arundinacea) growth improved likely due to the increase in tissue concentrations of $\mathrm{Ca}, \mathrm{Mg}$, and $\mathrm{S}$. At rates exceeding $120 \mathrm{~g} \mathrm{~kg}^{-1}$, the soil became too alkaline and cementation of the soil occurred as a result of the formation of ettringite $\left[\left(\mathrm{Ca}_{6} \mathrm{Al}_{2}\left(\mathrm{SO}_{4}\right)_{3}(\mathrm{OH})_{12} \cdot 26 \mathrm{H}_{2} \mathrm{O}\right)\right]$. With increasing application rate of the DFGD by-products, there was an increase in leachate $\mathrm{pH}, \mathrm{EC}$, dissolved organic $\mathrm{C}, \mathrm{Ca}, \mathrm{Mg}$, and $\mathrm{S}$. The concentrations of leachate $\mathrm{As}, \mathrm{B}, \mathrm{Cu}, \mathrm{Ni}$, and Se varied depending on the concentration of DFGD by-product and spoil type. Utilizing CCBs as 
a mine-spoil amendment may be more desirable than as an agronomic soil amendment because of the potential for plant uptake of trace elements by agronomic crops.

\section{Conclusions}

Each year, millions of megagrams of CCBs are disposed of in landfills and surface impoundments, which increases the likelihood of accidental releases to the environment. Certain CCBs, such as Class-C FAs and DFGD by-products, possess physical and chemical properties that make them potentially useful as soil liming materials. If a local source is available, CCBs may be a usable alternative to conventional agricultural liming materials for mitigating soil acidity in a manner that is economically viable. The presence of gypsum in DFGD by-products provides the additional benefit of reducing subsoil acidity by acting as a source of $\mathrm{Ca}^{2+}$ ions and lowering levels of exchangeable $\mathrm{Al}^{3+}$. However, the presence of trace elements and heavy metals warrants caution if CCBs are used as a soil amendment.

The results of this experiment support the hypothesis that when CCBs, specifically Class-C FA and DFGD by-product, are added to an acidic subsoil at a rate equivalent to the SMP buffer lime requirement, the soil $\mathrm{pH}$ after $40 \mathrm{~d}$ would be similar to the $\mathrm{pH}$ in reagent-grade $\mathrm{CaCO}_{3}$-amended soil. Results also supported the hypothesis that the $\mathrm{pH}$ of soil incubated with the DFGD by-product and Class-C FA at $2 \times$ the SMP buffer lime requirement would be greater than soil incubated with reagent-grade $\mathrm{CaCO}_{3}$. This experiment demonstrated that the relatively new DFGD by-product has similar liming characteristics to reagent-grade $\mathrm{CaCO}_{3}$ and a Class-C FA, which may provide a viable alternative use of DFGD by-product as a soil amendment and liming material and would diminish the need to dispose of these materials in landfills and surface impoundments.

\section{Acknowledgements}

This study was supported by a grant from the Arkansas Water Resources Center. Field assistance provided by Cory Johnson and laboratory assistance provided by Martin Striefler Jr. is appreciated.

\section{References}

[1] U.S. Energy Information Agency (USEIA) (2015) Annual Energy Outlook 2015 with Projections to 2040. U.S. Department of Energy, Ed., U.S. Energy Information Administration, Washington DC.

[2] Luther, L. (2010) Managing Coal Combustion Waste (CCW): Issues with Disposal and Use. Congressional Research Service, Washington DC.

[3] American Coal Ash Association (ACAA) (2008) 2007 Coal Combustion Product (CCP) Production \& Use Survey Results (Revised). American Coal Ash Association, Aurora, CO.

[4] U.S. Environmental Protection Agency (USEPA) (2015) Hazardous and Solid Waste Management System: Disposal of Coal Combustion Residuals from Electric Utilities. Washington DC.

[5] Wisconsin Electric (WE) (2013) Coal Combustion Products Utilization Handbook. Wisconsin Electric Power Company, Milwaukee, WI. 
[6] Adriano, D.C., Weber, J., Bolan, N.S., Paramasivam, S., Koo, B. and Sajwan, K.S. (2001) Effects of High Rates of Coal Fly Ash on Soil, Turfgrass, and Groundwater Quality. Water, Air, \& Soil Pollution, 135, 365-385.

[7] Kost, D.A., Bigham, J.M., Stehouwer, R.C., Beeghly, J.H., Fowler, R., Traina, S.J., Wolfe, W.E. and Dick, W.A. (2005) Chemical and Physical Properties of Dry Flue Gas Desulfurization Byproducts. Journal of Environmental Quality, 34, 676-686. http://dx.doi.org/10.2134/jeq2005.0676

[8] Foy, C.D. (1992) Soil Chemical Factors Limiting Plant Root Growth. Advances in Soil Sciences, 19, 97-149. http://dx.doi.org/10.1007/978-1-4612-2894-3_5

[9] Heylar, K.R. and Porter, W.M. (1989) Soil Acidification, Its Measurement, and the Processes Involved. In: Robson, A.D., Ed., Soil Acidity and Plant Growth, Academic Press, San Diego, CA. http://dx.doi.org/10.1016/b978-0-12-590655-5.50007-4

[10] Clark, R.B., Ritchey, K.D. and Baligar, V.C. (2001) Benefits and Constraints for Use of FGD Products on Agricultural Land. Fuel, 80, 821-828. http://dx.doi.org/10.1016/S0016-2361(00)00162-9

[11] United States Department of Agriculture-Natural Resources Conservation Service (USDANRCS) (2015) Official Series Description-Captina Series. https://soilseries.sc.egov.usda.gov/OSD_Docs/C/CAPTINA.html

[12] Gee, G.W. and Bauder, J.W. (1986) Particle-Size Analysis. In: Klute, A., Ed., Methods of Soil Analysis, Part 1. Physical and Mineralogical Methods, Agronomy Monograph No. 9, 2nd Edition, American Society of Agronomy/Soil Science Society of America, Madison, WI, 383-411.

[13] Sparks, D.L., Page, A.L., Helmke, P.A., Loeppert, R.H., Soltanpour, P.N., Tabatabai, M.A., Johnson, C.T. and Sumner, M.E. (1996) Methods of Soil Analysis. Part 3-Chemical Methods. Soil Science Society of America, Madison, WI.

[14] Cantrell, M.A. (2014) Leaching Characteristics of Selenium from Coal Fly Ash. M.S. Thesis, University of Arkansas.

[15] American Society for Testing and Materials (ASTM) International (2015) Standard Test Methods for Physical Testing of Quicklime, Hydrated Lime, and Limestone. ASTM International, West Conshohocken, PA.

[16] American Society for Testing and Materials (ASTM) International (2015) Standard Test Methods for Chemical Analysis of Limestone, Quicklime, and Hydrated Lime. ASTM International, West Conshohocken, PA.

[17] Saxton, K.E. and Rawls, W.J. (2006) Soil Water Characteristic Estimates by Texture and Organic Matter for Hydrologic Solutions. Soil Science Society of America Journal, 70, 15691578. http://dx.doi.org/10.2136/sssaj2005.0117

[18] Schlossberg, M.J., Waltz Jr., F.C. and Miller, W.P. (2006) Amelioration of Soil Acidity with Class-C Fly Ash: A Field Study. In: Sajwan, K.S., Twardowska, I., Punshon, T. and Alva, A.K., Eds., Coal Combustion Byproudcts and Environmental Issues, Springer Science \& Business Media, Berlin, 190-194. http://dx.doi.org/10.1007/0-387-32177-2_21

[19] Boynton, R.S. (1980) Chemistry and Technology of Lime and Limestone. Wiley-Interscience, New York.

[20] Stumm, W. and Morgan, J.J. (1981) Aquatic Chemistry: An Introduction Emphasizing Chemical Equilibria in Natural Waters. Wiley-Interscience, New York.

[21] Punshon, T., Adriano, D.C. and Weber, J.T. (2001) Effect of Flue Gas Desulfurization Residue on Plant Establishment and Soil and Leachate Quality. Journal of Environmental Quality, 30, 1071-1080. http://dx.doi.org/10.2134/jeq2001.3031071x 
[22] McCarty, G.W., Siddaramappa, R., Wright, R.J., Codling, E.E. and Gao, G. (1994) Evaluation of Coal Combustion Byproducts as Soil Liming Materials: Their Influence on Soil pH and Enzyme Activities. Biology and Fertility of Soils, 17, 167-172.

http://dx.doi.org/10.1007/BF00336317

[23] Sumner, M.E., Shahandeh, H., Bouton, J. and Hammel, J. (1986) Amelioration of an Acid Soil Profile through Deep Liming and Surface Application of Gypsum. Soil Science Society of America Journal, 50, 1254-1258. http://dx.doi.org/10.2136/sssaj1986.03615995005000050034x

[24] Wendell, R.R. and Ritchey, K.D. (1996) High-Calcium Flue Gas Desulfurization Products Reduce Aluminum Toxicity in an Appalachian Soil. Journal of Environmental Quality, 25, 1401-1410. http://dx.doi.org/10.2134/jeq1996.00472425002500060034x

[25] Stehouwer, R.C., Sutton, P., Fowler, R.K. and Dick, W.A. (1995) Minespoil Amendment with Dry Flue Gas Desulfurization By-Products: Element Solubility and Mobility. Journal of Environmental Quality, 24, 165-174. http://dx.doi.org/10.2134/jeq1995.00472425002400010023x

[26] Grisafe, D.A., Angino, E.E. and Smith, S.M. (1988) Leaching Characteristics of a HighCalcium Fly Ash as a Function of pH: A Potential Source of Selenium Toxicity. Applied Geochemistry, 3, 601-608. http://dx.doi.org/10.1016/0883-2927(88)90092-3

[27] Stehouwer, R.C., Sutton, P. and Dick, W.A. (1995) Minespoil Amendment with Dry Flue Gas Desulfurization By-Products: Plant Growth. Journal of Environmental Quality, 24, 861869. http://dx.doi.org/10.2134/jeq1995.0047242500240005011x

Submit or recommend next manuscript to SCIRP and we will provide best service for you:

Accepting pre-submission inquiries through Email, Facebook, LinkedIn, Twitter, etc.

A wide selection of journals (inclusive of 9 subjects, more than 200 journals)

Providing 24-hour high-quality service

User-friendly online submission system

Fair and swift peer-review system

Efficient typesetting and proofreading procedure

Display of the result of downloads and visits, as well as the number of cited articles

Maximum dissemination of your research work

Submit your manuscript at: http://papersubmission.scirp.org/

Or contact jep@scirp.org 